OPEN ACCESS

Edited by: Lars Lundqvist,

Swedish University of Agricultural

Sciences, Sweden

Reviewed by:

Thomas J. Dean,

Louisiana State University,

United States

Jeff Kuehny,

Louisiana State University,

United States

*Correspondence:

Frank W. Telewsk

telewski@msu.edu

Specialty section:

This article was submitted to

Forest Management,

a section of the journal

Frontiers in Forests and Global

Change

Received: 18 June 2020 Accepted: 07 December 2020

Published: 18 January 2021

Citation:

Telewski FW (2021) Mechanosensing and Plant Growth Regulators Elicited

During the Thigmomorphogenetic

Response.

Front. For. Glob. Change 3:574096 doi: 10.3389/ffgc.2020.574096

\section{Mechanosensing and Plant Growth Regulators Elicited During the Thigmomorphogenetic Response}

\author{
Frank W. Telewski* \\ W.J. Beal Botanical Garden and Campus Arboretum, Department of Plant Biology, Michigan State University, East Lansing, \\ MI, United States
}

The influence of mechanical bending or flexing of trees, due primarily to wind, on tree growth and development has been observed and reported for hundreds of years. This response was defined as the thigmomorphogenetic response in 1973. In general, the response of trees and other plants to bending is a reduction in extension/height growth, increase in radial growth, and increased allocation from above-ground to below-ground tissues accompanied by changes in biomechanical properties of the xylem. Within the last 50 years, significant advancements have been reported in characterizing the response of trees to this mechanical perturbation. Current research has advanced the understanding of how plants respond after mechanopreception via molecular signaling and physiological changes in growth regulation. This review provides insight into these subcellular reactions of thigmomorphogenesis and a summary of recent advances.

Keywords: wind, touch, thigmomorphogenesis, mechanosensing, mechanopreception, growth regulators

\section{INTRODUCTION}

External mechanical loading induces mechanical perturbation (MP) of trees and nonwoody plants via wind, rain, the brushing or touching of passing animals, pushing through soil, or accumulation of ice or snow and is known to induce a cascade of physiological, developmental, anatomical, and morphological responses termed thigmomorphogenesis (Table 1) (Jaffe, 1973). The reaction to MP by the mechanosensing response network has been shown to be dose dependent (Jaffe et al., 1980; Braam and Davis, 1990; Telewski et al., 1997; Telewski and Pruyn, 1998; Bonnesoeur et al., 2016; Kašpar et al., 2017). After perceiving a mechanical force, a series of signaling and subsequent growth regulator responses are triggered. This review article addresses the current state of knowledge concerning this physiological response pathway. The alteration of plant structure and function (anatomy, morphology, and mechanical properties) has been addressed in a previously published reviews (Telewski, 1995, 2006, 2012, 2016a,b; Jaffe et al., 2002; Gardiner et al., 2016).

\section{MECHANOSENSING AND GROWTH REGULATORS SIGNALING}

\section{Action Potential}

The first detectable response is a change in action potential and electrical resistance, which develops across the cell membrane within seconds after MP (Lund, 1931; Sibaoka, 1966; Asher, 1968; Pickard, 1971; Desbiez, 1973; Jaffe, 1976; Frachisse et al., 1985; de Jaegher and Boyer, 1989; Choi et al., 2016). The next measurable change occurs as an increase in intracellular $\mathrm{Ca}^{2+}$ functions as a secondary messenger of the mechanical signal in plants in response to numerous abiotic and 
TABLE 1 | Thigmo-mechanoresponse cascade flow diagram of the physiological responses after the induction of a mechanical perturbation.

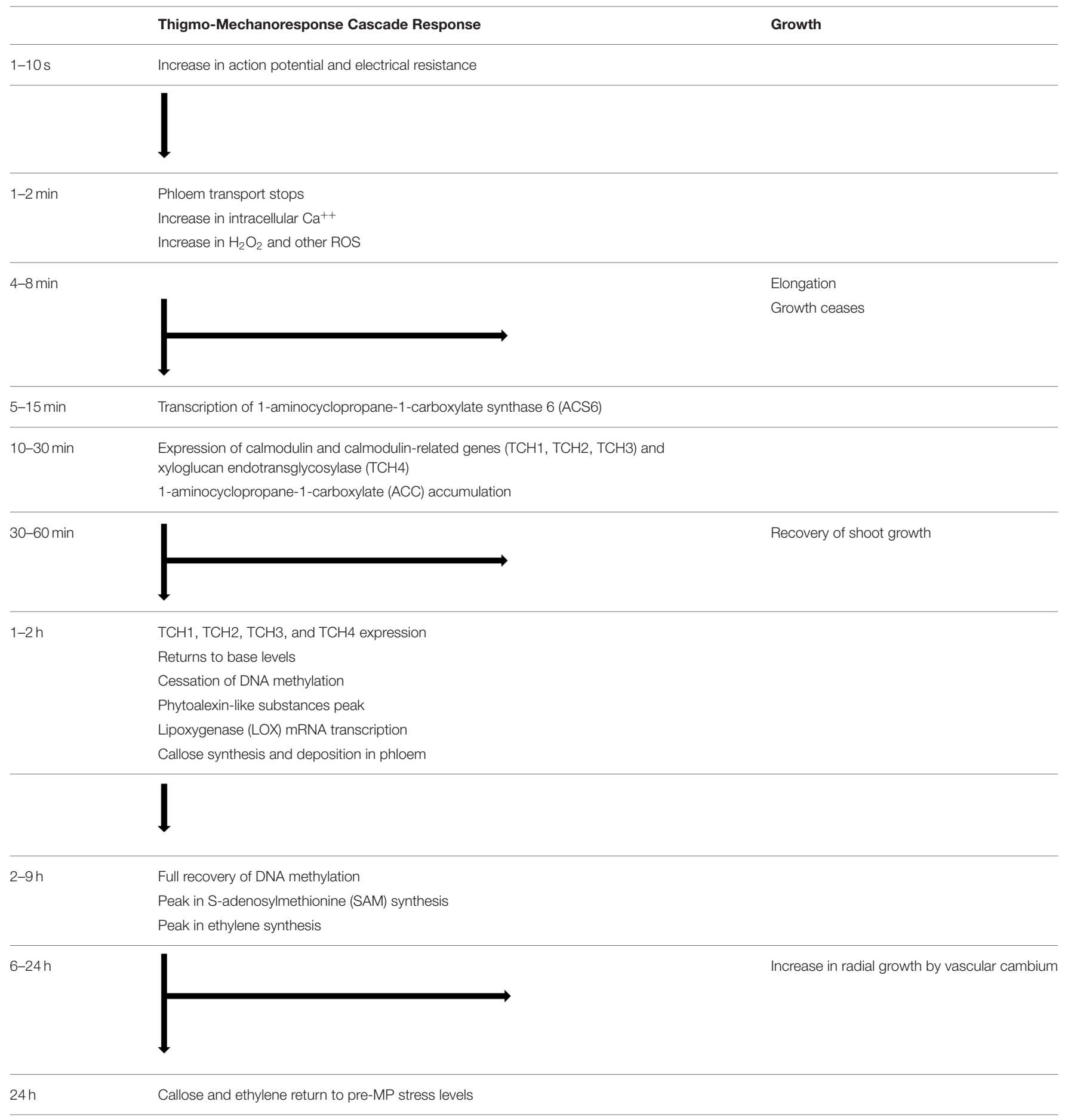

biotic stresses (Blume et al., 2000; Dodd et al., 2010; Batistič and Kudla, 2012; Choi et al., 2016). Such an accumulation of intracellular $\mathrm{Ca}^{2+}$ has been reported in plants and plant tissues exposed to MP (Thonat et al., 1993; Haley et al., 1995; Knight, 2000; Ishihara et al., 2017). For this reason, it is currently unclear if stretch-activated $\mathrm{Ca}^{2+}$ channels
(Ding and Pickard, 1993; Pickard and Fujiki, 2005) function in the primary perception or are triggered by the mechanosensing network proposed by Baluška et al. (2003, 2005). The function of stretch-activated channels is to facilitate the transport of $\mathrm{Ca}^{2+}$ across the cell membrane into the cell in response to MP (Ding and Pickard, 1993; Pickard and Fujiki, 2005). An 
increase in cytoplasmic calcium in response to MP has been documented in several plant systems (Toriyama and Jaffe, 1972; de Jaegher and Boyer, 1990; Knight et al., 1991, 1992; Trewavas and Knight, 1994; Legué et al., 1997; Pickard and Fujiki, 2005). Confirming the role of cytoplasmic calcium in mechanopreception, de Jaegher and Boyer (1990) were able to block the thigmomorphogenetic response by treating MP plants with EGTA, a calcium ion chelator, which also blocked peroxidase activity and ethylene biosynthesis, both of which are known to be involved downstream of the initial perception of MP.

\section{Reactive Oxygen Species}

Hydrogen peroxide $\left(\mathrm{H}_{2} \mathrm{O}_{2}\right)$ and other reactive oxygen species (ROS), also known as active oxygen species (AOS), are part of the defense response of plants that function as signaling molecules to a variety of stimuli. Fungal attack involves the mechanical insertion of a fungal penetration peg through the host cell wall stimulating ROS and AOS production by the host plant (Sutherland, 1991; Mehdy, 1994; Gus-Mayer et al., 1998). The release of ROS also occurs when transferring cell cultures or physical stirring cultures (Apostol et al., 1989; Legendre et al., 1993). Yahraus et al. (1995) induced an oxidative burst in Glycine $\max (\mathrm{L}$.) Merr. cells in response to osmotic stress (altered turgor pressure) and direct MP. Levels of soluble and cell wall-bound basic peroxidases increased $24 \mathrm{~h}$ after MP of Bryonia dioica Jacq. (Boyer et al., 1979). The induction of ROS and increase in cytosolic $\mathrm{Ca}^{2+}$ appear to be concurrent, and ROS have been suggested to regulate $\mathrm{Ca}^{2+}$ channel gating (Mori and Schroeder, 2004). Additionally, stress-induced $\mathrm{H}_{2} \mathrm{O}_{2}$ induces ethylene biosynthesis in plants (Van Breusegem et al., 2001), which is subsequently involved in a number of stress responses, which are addressed below. Tomatoes overexpressing glutathione peroxidase, a part of the ROS-scavenging system, exhibited a significantly reduced thigmomorphogenetic response (Herbette et al., 2011), further confirming the important role of ROS in the thigmomorphogenetic response. MP also has been shown to induce the defense and stress signaling molecule, nitric oxide (NO), in the leaves of Arabidopsis thaliana (L.) Heynh. (Garcês et al., 2001). NO induces stomatal closure and may protect the plant from desiccation during windy conditions when the boundary layer is stripped from the leaf surface. Subsequent research has shown that the touch-inducible gene CML24/TCH2, which codes for a $\mathrm{Ca}^{2+}$-binding protein (Braam and Davis, 1990; Delk et al., 2005; Lee et al., 2005), is required for NO accumulation (Tsai et al., 2007; Ma et al., 2008).

\section{Gene Up-Regulation}

Shortly after the sensing of an MP and the resulting action potential has been generated, a series of genes are transcribed. The rapid up-regulation (expression) of calmodulin and calmodulin-related genes (TCH1, TCH2, and TCH3) was observed in A. thaliana (L.) Heynh. (Arabidopsis) 10-30 min after mechanoperception of a touch, wind, or rain stimulus and returning to base levels by 1-2 h (Braam and Davis, 1990). Arabidopsis TCH4 encodes for a xyloglucan endotransglycosylase and was coexpressed with the other $\mathrm{TCH}$ genes (Xu et al., 1995). The expression of xyloglucan endotransglycosylase in response to wind was located in cells undergoing expansion (Antosiewicz et al., 1997). Galaud et al. (1993) observed a cessation of DNA cytosine methylation in $B$. dioica $1 \mathrm{~h}$ after the application of MP, with full recovery of methylation $3 \mathrm{~h}$ after MP. The authors also reported a peak in production of S-adenosylmethionine, a substrate for DNA methylation and a precursor for ethylene biosynthesis, co-occurred with the cessation of DNA methylation.

Touch, wind, and wounding all induced increased lipoxygenase (LOX) mRNA transcription in Triticum aestivum L. seedlings (Mauch et al., 1997). The MP induced response occurred within $1 \mathrm{~h}$ after treatment, and the amount of transcript was reported to be strongly dose-dependent. LOXs are involved or implicated in a number of metabolic pathways associated with plant growth and development, abscisic acid (ABA) biosynthesis, senescence, mobilization of lipid reserves, wound responses, resistance to pathogens, formation of fatty acid hydroperoxides, synthesis of jasmonic acid, and traumatic acid (Mauch et al., 1997). Controlled bending of young Populus tremula $\times$ Populus alba cv 717-1B4 stems stimulated an up-regulation of jasmonic acid and other plant abiotic stress and defense signaling pathways (Pomiès et al., 2017).

\section{Phloem Transport}

MP of stems of Phaseolus vulgaris L. and Gossypium hirsutum L. cv. "Stoneville 213" blocks phloem transport within 1-2 min after perturbation with full recovery of transport requiring 20$175 \mathrm{~min}$ (Jaffe and Telewski, 1984; Jaeger et al., 1988). Callose plugs are involved in blocking phloem sieve plates and slowing down or blocking phloem transport and have been observed in response to MP in stems of P. vulgaris and Pinus taeda L. $1 \mathrm{~h}$ after MP. The callose plugs peak after $9 \mathrm{~h}$ and reabsorbed after $25 \mathrm{~h}$ (Jaffe and Telewski, 1984). The rapid response of blocked phloem transport and the formation of callose plugs have not been directly linked. The mechanism of rapid phloem transport is still unknown. Callose deposition also occurs within 5 min of gravity stimulation in Zea mays L. and Pisum sativum L. Deposition of callose occurred first on the upper side of displaced stems, and after $2-3 \mathrm{~h}$, the pattern was reversed. The callose inhibitor, 2-deoxy-D-glucose, blocked callose formation and considerably reduced gravitropic bending in both species (Jaffe and Leopold, 1984).

\section{Plant Growth Regulators}

Ethylene biosynthesis has been reported to be a fairly ubiquitous response to a number of environmental stresses including mechanical stress and serves as a signaling molecule (see Abeles et al., 1992; Bleecker and Kende, 2000). Both 1-aminocyclopropane-1-carboxylate synthase (ACS6) and 1aminocyclopropane-1-carboxylate (ACC) are involved in the ethylene biosynthetic pathway and are stimulated by MP in Arabidopsis leaves peaking at 5-15 $\mathrm{min}$ and $15-30 \mathrm{~min}$, respectively (Arteca and Arteca, 1999). MPs induced by wind, touch, and dynamic flexing have all been shown to induce ethylene formation in vascular plants. It was the first plant growth regulator to be implicated in the response to MP (Goeschl et al., 1966; Brown and Leopold, 1973; Robitaille and Leopold, 
1974; Hiraki and Ota, 1975; Jaffe and Biro, 1979; Biro and Jaffe, 1984; Prasad and Cline, 1985; Telewski and Jaffe, 1986; de Jaegher et al., 1987; Telewski, 1990; Emery et al., 1994; Onguso et al., 2006; Love et al., 2009). Researchers were also able to mimic the effects of MP with the application of exogenous ethylene (Mitchell, 1977; Biro et al., 1980; Erner et al., 1980; Telewski and Jaffe, 1981; Erner and Jaffe, 1983; Prasad and Cline, 1985). More recently, Pomiès et al. (2017) reported that a single MP either up- or down-regulated (differential expression) $6 \%$ (2,663 genes) of the P. tremula $\times$ P. alba cv. $717-$ 1B4 genome, including ethylene synthesizing genes. However, Boyer et al. (1983) reported MP reduced ethylene production but increased the ability for conversion of ACC to ethylene, suggesting an increased expression or increased activity of ACC synthase in $B$. dioica. The application of exogenous ethylene and overexpression of ACC oxidase stimulate cambial growth in P. tremula $\times$ Populus tremuloides, whereas etr1-1 (ethylene receptor mutant) transformed plants did not respond to ethylene application. When exposed to MP, the etr1-1 transformed plants exhibited no increase in radial growth and suppressed tension wood formation, as well as no reduction in height growth, indicating ethylene is key to a response to MP (Love et al., 2009). However, Johnson et al. (1998) reported Arabidopsis ethylene mutants ert 1 and ein2, which are deficient in sensing or responding to ethylene, did respond to MP; specifically, there was a normal thigmomorphogenetic reduction in inflorescence height growth in response to MP similarly to wild-type plants. The authors did not report any data for inflorescence diameter growth. The authors concluded, “... the ERT1 and EIN2 protein functions are not required for developmental and molecular responses to mechanical stimulation.” Anten et al. (2006) using transgenic Nicotiana tabacum L. modified with the Arabidopsis ERT1 allele reported similar results to those of Johnson et al. (1998). The conclusion regarding the role of ethylene in the thigmomorphogenetic response was again presented as “...a fully functional ethylene pathway is not required for aspects of thigmomorphogenesis." (Chehab et al., 2011). As presented earlier, Paul-Victor and Rowe (2011) did not observe any change in the basal diameter of Arabidopsis inflorescence exposed to MP compared to control plants, whereas inflorescence height is significantly reduced in response to MP. The role of ethylene in response to MP appears to effect secondary growth and subsequent development and differentiation of the vascular cambium and may not impact elongation or height growth associated with the primary growth of the apical meristems of inflorescence stalks in Arabidopsis (Anten et al., 2006; Telewski, 2006). Contrary to Chehab et al. (2011) study on inflorescence spikes, Okamoto and Takahashi (2019) observed that MP inhibits root elongation in Arabidopsis. The application of ACC reduced the root elongation of Arabidopsis, whereas the application of either silver ions or salicylic acid restored the growth in the MP roots.

Auxin has also been implicated in the thigmomorphogenetic response (Boyer, 1967; Mitchell, 1977; Hofinger et al., 1979; Erner and Jaffe, 1982; Jedrzejuk et al., 2020). MP reduced the endogenous level of auxin in B. dioica, and the application of exogenous auxin restored the growth rate in MP plants (Boyer,
1967). A reduction in auxin content after MP was reported in MP plants of Solanum lycopersicum L., Plantago major L., and Solanum tuberosum L. (Saidi et al., 2010; Onoda and Anten, 2011; Markovic et al., 2016). The MP-induced reduction in stem elongation during primary growth is the result of increases in the activity of indoleacetic acid (IAA) oxidase, phenylalanine ammonia-lyase, cinnamyl alcohol dehydrogenase, or defense-related peroxidase (Cipollini, 1998; Saidi et al., 2010; Jedrzejuk et al., 2020). Auxin is known to exhibit cross-talk interaction with ethylene. Erner and Jaffe (1982) hypothesized the accumulation of auxin-like plant growth regulators resulted from ethylene production earlier in the thigmomorphogenetic response and was responsible for the reduction in internode (shoot) elongation. However, this hypothesis was challenged by the subsequent observation that ethylene mutants still respond to MP with a reduction in shoot elongation (Johnson et al., 1998).

A role for ABA has also been reported in thigmomorphogenesis with higher levels of ABA reported in response to MP (Jeong and Ota, 1980; Erner and Jaffe, 1982; Beyl and Mitchell, 1983). ABA is a growth antagonist, and its increase in response to MP could facilitate the observed reduction in extension growth in response to MP. In addition to its role in NO accumulation, the $C M L 24 / T C H 2$ gene also has been shown to be required in the ABA responses (Delk et al., 2005) and has been suggested to be linked to ABA's role in thigmomorphogenesis (Chehab et al., 2011).

MP leads to a significant reduction in endogenous gibberellin (GA) (Suge, 1978; Takahashi and Suge, 1980). Unfortunately, no time course of GA content was conducted. MP in P. vulgaris was observed to decrease after 29 days of daily application of bending for $1 \mathrm{~min}$ (Suge, 1978). MP in cucumber decreased growth and increased the number of pistillate flowers, a process regulated by a reduction in GA. The application of $\mathrm{GA}_{4+7}$ to MP plants nullified the effect of MP on growth and floral sex expression. The application of silver nitrate, an antiethylene agent, reversed the effect of MP on floral sex expression but did not restore normal growth (Takahashi and Suge, 1980). The endogenous levels of $\mathrm{GA}_{4}, \mathrm{GA}_{12}, \mathrm{GA}_{15}$, and $\mathrm{GA}_{34}$ declined significantly in MP Arabidopsis. The decrease in GA content was reported to be consistent with the decreased rate of inflorescence extension growth and leaf morphology. The application of exogenous bioactive form of gibberellic acid $\left(\mathrm{GA}_{4}\right)$ reversed the decreased rate of extension growth in MP plants. MP also induced the expression of AtGA2ox7, which encodes an enzyme involved in GA catabolism. The loss-of-function Arabidopsis ga2ox7 did not respond to MP (João et al., 2015). The authors suggest ga2ox7 is a key regulator of thigmomorphogenesis, and MP-induced changes in morphology are dependent on GA catabolism.

In terms of thigmo-responses, jasmonates (JAs) were first implicated in the thigmonastic coiling response of tendrils (Falkenstein et al., 1991; Weiler, 1993). The octadecanoid 12oxo-phytodienoic acid, a precursor for JA, increased severalfold in response to MP, inducing a thigmomorphogenetic response in beans, and the application of coronatine triggered a thigmomorphogenetic response (Stelmach et al., 1998). MP Medicago truncatula Gaertn. plants exhibited higher levels of JA 
and reduced height growth compared to control plants (Tretner et al., 2008). A study on the allene oxide synthase (AOS) mutant in Arabidopsis further implicated the role of JA in the thigmomorphogenetic response. The AOS mutation disrupts JA and other oxylipin synthesis. AOS mutant plants did not exhibit a thigmomorphogenetic response when exposed to MP (Chehab et al., 2012).

Cytokinin content was elevated in the xylem exudate of MP Helianthus annuus L. stems; however, it was reduced in the leaves of MP plants (Beyl and Mitchell, 1983). The entire field elucidating the role of plant growth regulators in the postmechanopreception-thigmomorphogenetic response is still open for investigation. The increasing number of metabolic mutants in Arabidopsis available for study will help clarify the role different growth regulators, signaling compounds, and cytoskeleton structure have in the thigmomorphogenetic response.

\section{SUMMARY AND CONCLUSIONS}

Thigmomorphogenesis is one of several plant responses to touch requiring a cellular-level mechanosensing mechanism involving the cytoskeleton connected to the plasma membrane and cell wall. The plasma membrane contains mechanosensitive ion channels, which facilitate signaling via the movement of $\mathrm{Ca}^{++}$between the apoplast and symplast. Following mechanopreception, a cascade of physiological responses occurs, involving up- or down-regulation of gene expression and plant growth regulators. These physiological changes further influence cell expansion and division in meristematic regions. Altering the developing anatomy and morphology and ultimately allometry of both above- and below-ground plant organs. In general, the growth response is characterized by a decrease in height or extension growth (primary growth) and an increase in radial growth (secondary growth), which increases stem taper. The change in growth pattern also results in a reallocation of growth from shoots to roots increasing the root-to-shoot ratio and decreasing reproductive potential by reducing flower number and delaying time to flowering. Changes in the anatomy and cellular structure modify the biomechanical properties of the stem, lowering the stem's resistance to bending (thus increasing the ability of the stem to absorb bending energy), but increasing overall stem stiffness by increasing overall stem diameter. Shorter stems and branches and smaller leaves reduce the profile presented to wind and thus reduce drag on the plant crown. Because the thigmomorphogenetic response shares many similarities with other plant stress responses, plants exposed to MP also exhibit greater resistance to other biotic and abiotic stresses. Research into the mechanosensing and biochemical/physiological response of plants to MP has advanced significantly over the past 60 years. More recent advances in molecular biology and genetics have accelerated this understanding. The literature cited in this review is a compilation of many studies which investigate a multitude of different plant species reflecting a broad diversity of plant growth forms and strategies, from short-lived annuals of both dicot and monocot taxa to long-lived woody perennials, sessile plants to vining plants to arborescent plants. As reviewed here, differences in results for different physiological systems might be simply a result of different biological requirement needed to support a specific plant organ, growth form, or ecological strategy. For example, Arabidopsis is a short-lived sessile annual composed of a rosette of leaves and a flower spike. The only structure that rises above ground level and is potentially exposed to wind is its floral spike upon which most MP studies in this species have been conducted. This organ is an ephemeral structure of primary growth tissues lacking secondary growth and specialized in supporting flowers/reproduction. B. dioica and Cucurbita pepo are both vining plants that have secondary growth but rely on other plants or objects for mechanical support. Monocotyledonous angiosperms such as Triticum and Zea do not possess a vascular cambium. The annual dicotyledonous angiosperms including Phaseolus, Helianthus, Nicotiana, and Medicago possess a vascular cambium but do not achieve great height growth. Within arborescent taxa, within the same species, differences in parentage and genetic lines can result in different degrees of growth responses to MP, which has been reported in both dicotyledonous angiosperms and coniferales (conifers). This has been clearly demonstrated in hybrid Populus clones and Pinus taeda half-sib families. This latter fact provides some potential for tree selection and breeding programs to identify traits that convey increased resistance to wind-induced damage to forest plantations such as wind-throw or stem snap (Telewski and Moore, 2016).

With a few notable exceptions (for reviews, see Telewski, $1995,2006,2012,2016 a, b)$, the majority of arborescent woody tree species that fall within the dicotyledonous angiosperms and conifers exhibit some degree of a thigmomorphogenetic response when exposed to wind or other MP. Variations within this response reported in past studies likely arose due to the type and intensity of the MP applied to the plant and the underlying genetics and life history. Standardizing force application has contributed significantly to understanding the amount of force required to induce a response in trees (Coutand et al., 2000). The application of clonal or half- or full-sib technology will also reduce variability within a study group/population. This will potentially lead to the identification of potential gene candidates to further elucidate the variability in the thigmomorphogenetic response. Such an approach can be further advanced by incorporating specific genetic mutations and gene silencing techniques to isolate and identify key elements in the response pathway. Further investigation into the role of ACC and ethylene in the response of woody plants to determine if their role in the thigmomorphogenetic response is restricted to radial, secondary growth of the vascular cambium and not a reduction in height growth controlled by the apical meristem will be critical. Likewise, further elucidation of the timing and role that down-regulation of GA has on the inhibition of height growth is needed. Previous studies have reported a cessation of height growth shortly after MP with a recovery within an hour afterward. Does this growth cessation involve the down-regulation of GA, or is down-regulation involved later in the response pathway? Currently, no studies have investigated the role of mechanoperception and growth regulation in the 
development of roots in trees, although changes in morphology and anatomy have been reported. It would be interesting to determine if the response to wind and other MP induces similar responses in roots or if there are subtle differences given the nature of the root's structure and function in anchorage as opposed to withstanding bending and sway of the branches and trunk. Ultimately, a better understanding of the interactions of gene expression and growth and development could be applied

\section{REFERENCES}

Abeles, F. B., Morgan, P. W., and Saltveit, M. E. Jr. (1992). Ethylene in Plant Biology, 2nd edn. San Diego, CA: Academic Press, 414.

Anten, N. P. R., Casado-Garcia, R., Pierik, R., and Pons, T. L. (2006). Ethylene sensitivity affects changes in growth patterns, but not stem properties, in response to mechanical stress in tobacco. Physiol. Plantarum 128, 274-282. doi: 10.1111/j.1399-3054.2006.00736.x

Antosiewicz, D. M., Purugganan, M. M., Polisensky, D. H., and Braam, J. (1997). Cellular localization of Arabidopsis xyloglucan endotransglycosylase-related proteins during development and after wind stimulation. Plant Physiol. 115, 1319-1328. doi: 10.1104/pp.115.4.1319

Apostol, I., Low, P. S., and Heinstein, P. (1989). Effect of age of cell suspension cultures on susceptibility to a fungal elicitor. Plant Cell Rep. 7, 692-695.

Arteca, J.M., and Arteca, R. N. (1999). A multi-responsive gene encoding 1aminocyclopropane-1-carboxylate synthase (ACS6) in mature Arabidopsis leaves. Plant Mol. Biol. 39, 209-219. doi: 10.1023/A:1006177902093

Asher, W. C. (1968). Response of pine seedlings to mechanical stimulation. Nature 217, 134-136. doi: 10.1038/217134a0

Baluška, F., Šamaj, J., Wojtazek, P., and Volkmann, D., Menzel, D. (2003). Cytoskeleton-plasma membrane-cell wall continuum in plants. Emerging links revisited. Plant Physiol. 133, 483-491. doi: 10.1104/pp.103.027250

Baluška, F., Volkmann, D., and Menzel, D. (2005). Plant synapses: actin based domains for cell-to-cell communications. Trends Plant Sci. 10, 106-111. doi: 10.1016/j.tplants.2005.01.002

Batistič, O., and Kudla, J. (2012). Analysis of calcium signaling pathways in plants. Biochim. Biophys. Acta 1820, 1283-1293. doi: 10.1016/j.bbagen.2011.10.012

Beyl, C. A., and Mitchell, C. A. (1983). Alteration of growth, exudation rate, and endogenous hormone profiles in mechanically dwarfed sunflower. J. Am. Soc. Horticult. Sci. 108, 257-262.

Biro, R. L., Hunt, E. R., Erner, Y., and Jaffe, M. J. (1980). Thigmomorphogenesis: changes in cell division and elongation in the internodes of mechanicallyperturbed or ethrel-treated bean plants. Ann. Bot. 45, 655-664. doi: 10.1093/oxfordjournals.aob.a085874

Biro, R. L., and Jaffe, M. J. (1984). Thigmomorphogesis: ethylene evolution and its role in the changes observed in mechanically perturbed bean plants. Physiol. Plantarium 62, 289-296. doi: 10.1111/j.1399-3054.1984.tb04575.x

Bleecker, A. B., and Kende, H. (2000). Ethylene: a gaseous signal molecule in plants. Annu. Rev. Cell Dev. Biol. 16, 1-18. doi: 10.1146/annurev.cellbio.16.1.1

Blume, B., Nürnberger, T., Nass, N., and Scheel, D. (2000). Receptor-mediated increase in cytoplasmic free calcium required for activation of pathogen defense in parsley. Plant Cell. 12, 1425-1440. doi: 10.1105/tpc.12.8.1425

Bonnesoeur, V., Constant, T., Moulia, B., and Fournier, M. (2016). Forest trees filter chronic wind-signals to acclimate to high winds. New Phytol. 210, 850-860. doi: 10.1111/nph.13836

Boyer, N. (1967). Modifications de la croissance de la tige de Bryone (Bryonia dioica) a la suite d'irritations tactiles. CR Acad. Sci. Paris 264, 2114-2117.

Boyer, N., Desbiez, M. O., Hofinger, M., and Gaspar, T. (1983). Effect of lithium on thigmomorphogenesis in Bryonia dioica ethylene production and sensitivity. Plant Physiol. 72, 522-525. doi: 10.1104/pp.72.2.522

Boyer, N., Gaspar, T., and Lamond, M. (1979). Changes in isoperoxidases and in the growth rate of Bryonia diocia internodes after mechanical rubbing. Z. Pflanzenphysiol. 93, 459-470. doi: 10.1016/S0044-328X(79) 80180-4 for trait selection in tree improvement programs to increase the stability of forest and plantations to withstand the projected increase in winds associated with frontal and cyclonic storm systems forecast in climate change models.

\section{AUTHOR CONTRIBUTIONS}

FT is solely responsible for this publication.

Braam, J., and Davis, R. W. (1990). Rain-, wind-, and touch-induced expression of calmodulin and calmodulin-related genes in Arabidopsis. Cell 60, 357-365. doi: 10.1016/0092-8674(90)90587-5

Brown, K. M., and Leopold, A. C. (1973). Ethylene and the regulation of growth in pine. Can. J. For. Res. 3, 143-145. doi: 10.1139/x73-019

Chehab, E. W., and Wang,Y., Braam, J. (2011). "Mechanical force responses of plant cells and plants," in Mechanical Integration of Plant Cells and Plants, ed P. Wojtaszek (Berlin; Heidelberg: Springer), 173-194.

Chehab, E. W., Yao, C., Henderson, Z., Kim, S., and Braam, J. (2012). Arabidopsis touch-induced morphogenesis is jasmonate mediated and protects against pests. Curr. Biol. 22, 701-706. doi: 10.1016/j.cub.2012.02.061

Choi, W. G., Hilleary, R., Swanson, S. J., Kim, S. H., and Gilroy, S. (2016). Rapid, long-distance electrical and calcium signaling in plants. Annu. Rev. Plant Biol. 67, 287-307. doi: 10.1146/annurev-arplant-043015-112130

Cipollini, D. F., (1998). The induction of soluble peroxidase activity in bean leaves by wind-induced mechanical perturbation. Am. J. Bot. 85, 1586-1591. doi: $10.2307 / 2446485$

Coutand, C., Julien, J. L., Moulia, B., Mauget, J. C., and Guitard, D. (2000). Biomechanical study of the effect of a controlled bending on tomato stem elongation: global mechanical analysis. J. Exp. Bot. 51, 1813-1824. doi: 10.1093/jexbot/51.352.1813

de Jaegher, G., and Boyer, N. (1989). "On the role of membranes and calcium in signal perception and transduction in thigmomorphogenesis of Bryonia dioica," in Intra and Intercellular Communications in Higher Plants: Reception, Transmission, Storage and Expression of Messages.- INRA editions, eds B. Millet and H. Greppin (Paris: INRA), 29-33.

de Jaegher, G., and Boyer, N. (1990). "On the role of membranes and calcium in signal perception and transduction in Thigmomorphogenesis of Bryonia dioica," in Intra- and Intercellular Communications in Plants, eds B. Millet, H. Greppin (Paris: INRA), 29-39.

de Jaegher, G., Boyer, N., Bon, M. C., and Gaspar, T. (1987). Thigmomorphogenesis in Bryonia dioica: early events in ethylene biosynthesis pathway. Biochem. Physiol. Pflanzen 18:49-56. doi: 10.1016/S0015-3796(87) 80037-9

Delk, N. A., Johnson, K. A., Chowdhury, N. I., and Braam, J. (2005). CML24, regulated in expression by diverse stimuli, encodes a potential $\mathrm{Ca}^{2+}$ sensor that functions in responses to abscisic acid, daylength, and ion stress. Plant Physiol. 139, 240-253. doi: 10.1104/pp.105.062612

Desbiez, M. O. (1973). Précisions sur le micanisme des corrélations entre bourgeons cotylédonaires induites par des stimulations mécaniques du cotylédon chez Bidens pilosus L.- Z. Pflanzenphysiol. 69, 174-180. doi: 10.1016/S0044-328X(73)80035-2

Ding, J. P., and Pickard, B. G. (1993). Mechanosensory calciumselective cation channels in epidermal cells. Plant J. 3, 83-110. doi: 10.1046/j.1365-313X.1993.t01-4-00999.x

Dodd, A. N., Kudla, J., and Sanders, D. (2010). The language of calcium signaling. Annu. Rev. Plant Biol. 61, 593-602. doi: 10.1146/annurev-arplant-070109-104628

Emery, R. J. N., Reid, D. M., and Chinnappa, C. C. (1994). Phenotypic plasticity of stem elongation in two ecotypes of Stellaria longipes: the role of ethylene and response to wind. Plant Cell Environ. 17, 691-700. doi: 10.1111/j.1365-3040.1994.tb00161.x

Erner, Y., Biro, R., and Jaffe, M. J. (1980). Thigmomorphogenesis: evidence for a translocatable thigmomorphogenetic factor induced by mechanical 
perturbation of beans (Phaseolus vulgaris). Physiol. Plantarum 50, 21-25. doi: 10.1111/j.1399-3054.1980.tb02677.x

Erner, Y., and Jaffe, M. J. (1982). Thigmomorphogenesis: the involvement of auxin and abscisic acid in growth retardation due to mechanical perturbation. Plant Cell Physiol. 23, 935-941.

Erner, Y., and Jaffe, M. J. (1983). Thigmomorphogenesis: membrane lipid and protein changes in bean plants as affected by mechanical perturbation and ethrel. Physiol. Plantarum 58, 197-203. doi: 10.1111/j.1399-3054.1983.tb04169.x

Falkenstein, E., Groth, B., Mithofer, A., and Weiler, E. W. (1991). Methyl jasmonate and a-linolenic acid are potent inducers of tendril coiling. Planta 185, 316-322. doi: 10.1007/BF00201050

Frachisse, J. M., Desbiez, M. O., Champagnat, P., and Thellier, M. (1985). Transmission of a traumatic signal via a wave of electric depolarization, and induction of correlations between the cotyledonary buds in Bidens pilosus. Physiol. Plant. 64, 48-52. doi: 10.1111/j.1399-3054.1985.tb01211.x

Galaud, J.-P., Gaspar, T., and Boyer, N. (1993). Inhibition of internode growth due to mechanical stress in Bryonia dioica: relationship between changes in DNA methylation and ethylene metabolism. Physiol. Plantarium 87, 25-30. doi: 10.1034/j.1399-3054.1993.870105.x

Garcês, H., Durzan, D., and Pedroso, M. C. (2001). Mechanical stress elicits nitric oxide formation and DNA fragmentation in Arabidopsis thaliana. Ann. Bot. 87, 567-574. doi: 10.1006/anbo.2000.1356

Gardiner, B., Berry, P., and Moulia, B. (2016). Review: Wind impacts on plant growth, mechanics and damage. Plant Sci. 245, 94-118. doi: 10.1016/j.plantsci.2016.01.006

Goeschl, J. D., Rappaport, L., and Pratt, H. K. (1966). Ethylene as a factor regulating the growth of pea epicotyls subjected to physical stress. Plant Physiol. 41:877-884. doi: 10.1104/pp.41.5.877

Gus-Mayer, S., Naton, B., Hahlbrock, K., and Schmelzer, E. (1998). Local mechanical stimulation induces components of the pathogen defense response in parsley. Proc. Natl. Acad. Sci. U. S. A. 95, 8398-8403. doi: $10.1073 /$ pnas.95.14.8398

Haley, A. N. N., Russell, A. J., Wood, N., Allan, A. C., Knight, M., Campbell, A. K., et al. (1995). Effects of mechanical signaling on plant cell cytosolic calcium. Proc. Natl. Acad. Sci. U. S. A. 92, 4124-4128. doi: 10.1073/pnas.92.10.4124

Herbette, S., de Larouhe, D. T., Drevet, J. R., and Roeckel-Drevet, P. (2011). Transgenic tomatoes showing higher glutathione peroxidase antioxidant activity are more resistant to an abiotic stress but more susceptible to biotic stresses. Plant Sci. 180, 548-553. doi: 10.1016/j.plantsci.2010.12.002

Hiraki, Y., and Ota, Y. (1975). The relationship between growth inhibition and ethylene production by mechanical stimulation in Lilium longiflorum. Plant Cell Physiol. 16, 185-189. doi: 10.1093/oxfordjournals.pcp.a075120

Hofinger, M., Chapelle, B., Boyer, N., and Gaspar, T. (1979). GC-MS Identification and titration of IAA in mechanically perturbed Bryonia-dioica. Plant Physiol. 63:S-52.

Ishihara, K. L., Lee, E. K. W., and Borthakur, D. (2017). Thigmomorphogenesis: changes in morphology, biochemistry, and levels of transcription in response to mechanical stress in Acacia koa. Can. J. For. Res. 47, 583-593. doi: 10.1139/cjfr-2016-0356

Jaeger, C. H., Goeschl, J. D., Magnuson, C. E., Fares, Y., and Strain, B. R. (1988). Short-term response of phloem transport to mechanical perturbation. Physiol. Plantarum 72, 588-594. doi: 10.1111/j.1399-3054.1988.tb09169.x

Jaffe, M. (1976). Thigmomorphogenesis: electrical resistance and mechanical correlates of the early events of growth retardation due to mechanical stimulation in beans. Z. Pflanzenphyiol. 78, 24-32. doi: 10.1016/S0044-328X(76)80136-5

Jaffe, M. J. (1973). Thigmomorphogenesis: the response of plant growth and development to mechanical stimulation. Planta 114, 143-157. doi: $10.1007 / \mathrm{BF} 00387472$

Jaffe, M. J., and Biro, R. L. (1979). "Thigmomorphogenesis: the effect of mechanically perturbation on the growth of plants with special reference to anatomical changes, the role of ethylene, and interaction with other environmental stresses," in Stress Physiology of Crop Plants, eds H. Mussell, R. Staples (New York, NY: John Wiley and Sons), 25-59.

Jaffe, M. J., Biro, R. L., and Bridle, K. (1980). Thigmomorphogenesis: calibration of the parameters of the sensory function in beans. Physiol. Plantarum 49, 410-416. doi: 10.1111/j.1399-3054.1980.tb03326.x
Jaffe, M. J., and Leopold, A. C. (1984). Callose deposition during gravitropism of Zea mays and Pisum sativum and its inhibition by 2-deoxy-D-glucose. Planta 161, 20-26. doi: 10.1007/BF00951455

Jaffe, M. J., Leopold, A. C., and Staples, R. A. (2002). Thigmo responses in plants and fungi. Am. J. Bot. 89, 375-382. doi: 10.3732/ajb.89.3.375

Jaffe, M. J., and Telewski, F. W. (1984). "Thigmomorphogenesis: callose and ethylene in the hardening of mechanically stressed plants," in Phytochemical Adaptations to Stress, eds B. N. Timmermann, C. Steelink, F. A. Loewus (Boston, MA: Springer US), 79-95.

Jedrzejuk, A., Kuzma, N., Nawrot, K., Budzyński, R., and Orłowski, A. (2020). Mechanical stimulation affects growth dynamics, IAA content and activity of POD and IAA oxidase in Petunia $\times$ atkinsiana. Sci. Horticult. 274:109661. doi: 10.1016/j.scienta.2020.109661

Jeong, Y.-H., and Ota,Y. (1980). A relationship between growth inhibition and abscisic acid content by mechanical stimulation in rice plants. Jpn. J. Crop Sci. 49, 615-616. doi: 10.1626/jcs.49.615

João, M., Lange, P., and Lange, T. (2015). Touch-induced changes in Arabidopsis morphology dependent on gibberellin breakdown. Nat. Plants 1:15023. doi: 10.1038/nplants.2014.25

Johnson, K. A., Sistrunk, M. L., Polisensky, D. H., and Braam, J. (1998). Arabidopsis thaliana responses to mechanical stimulation do not require ETR1 or EIN2. Plant Physiol. 116, 643-649. doi: 10.1104/pp.116.2.643

Kašpar, J., Hošek, J., and Treml, V. (2017). How wind affects growth in treeline Picea abies. Alp Bot. 127, 109-120. doi: 10.1007/s00035-017-0186-x

Knight, H. (2000). Calcium signaling during abiotic stress in plants. Intern. Rev. Cytol. 195, 269-324. doi: 10.1016/S0074-7696(08)62707-2

Knight, M. R., Campbell, A. K., Smith, S. M., and Trewavas, A. J. (1991). Transgenic plant aequorin reports the effects of touch and cold-shock and elicitors on cytoplasmic calcium. Nature 352, 524-526. doi: 10.1038/352524a0

Knight, M. R., Smith, S. M., and Trewavas, A. J. (1992). Wind-induced plant motion immediately increases cytosolic calcium. Proc. Natl. Acad. Sci. U. S. A. 89, 4967-4971. doi: 10.1073/pnas.89.11.4967

Lee, D., Polisensky, D. H., and Braam, J. (2005). Genome-wide identification of touch-and darkness-regulated Arabidopsis genes: a focus on calmodulin-like and XTH genes. New Phytol. 165, 429-444. doi: 10.1111/j.1469-8137.2004.01238.x

Legendre, L., Rueter, S., Heinstein, P. F., and Low, P. S. (1993). Characterization of the oligogalacturonide-induced oxidative burst in cultured soybean (Glycine max) cells. Plant Physiol. 102, 233-240. doi: 10.1104/pp.102.1.233

Legué, V., Blancaflor, E., Wymer, C., Perbal, G., Fantin, D., and Gilroy, S. (1997). Cytoplasmic free $\mathrm{Ca}^{2+}$ in Arabidopsis roots changes in response to touch but not gravity. Plant Physiol. 114, 789-800. doi: 10.1104/pp.114.3.789

Love, J., Björklund, S., Vahala, J., Hertzberg, M., Kangasjärvi, J., and Sundberg, B. (2009). Ethylene is an endogenous stimulator of cell division in the cambial meristem of Populus. Proc. Natl. Acad. Sci. U. S. A. 106, 5984-5989. doi: 10.1073/pnas.0811660106

Lund, E. J. (1931). External polarity potentials in the apex of the Douglas fir before and after mechanical stimulation. Plant Physiol. 6, 507-517. doi: 10.1104/pp.6.3.507

Ma, W., Smigel, A., Tsai, Y. C., Braam, J., and Berkowitz, G. A. (2008). Innate immunity signaling: cytosolic $\mathrm{Ca}^{2+}$ elevation is linked to downstream nitric oxide generation through the action of calmodulin or a calmodulin-like protein. Plant Physiol. 148, 818-828. doi: 10.1104/pp.108. 125104

Markovic, D., Nikolic, N., Glinwood, R., Seisenbaeva, G., and Ninkovic, V. (2016). Plant responses to brief touching: a mechanism for early neighbour detection? PLoS One 11:e0165742. doi: 10.1371/journal.pone.01 65742

Mauch, F., Kmecl, A., Schaffrath, U., Volrath, S., Gorlach, J., Ward, E., et al. (1997). Mechanosensitive expression of a lipoxygenase gene in wheat. Plant Physiol. 114, 1561-1566. doi: 10.1104/pp.114.4.1561

Mehdy, M. C. (1994). Active oxygen species in plant defense against pathogens. Plant Physiol. 105, 467-472. doi: 10.1104/pp.105.2.467

Mitchell, C. A. (1977). Influence of mechanical stress on auxin-stimulated growth on excised pea stem sections. Physiol. Plantarum 41, 129-134. doi: 10.1111/j.1399-3054.1977.tb05543.x

Mori, I. C., and Schroeder, J. I. (2004). Reactive oxygen species activation of plant $\mathrm{Ca}^{2+}$ channels. A siginaling mechanism in polar growth, hormone 
transduction, stress signaling, and hypothetically mechanotransduction. Plant Physiol. 135, 702-708 doi: 10.1104/pp.104.042069

Okamoto, T., and Takahashi, T. (2019). Ethylene signaling plays a pivotal role in mechanical-stress-induced root-growth cessation in Arabidopsis thaliana. Plant Signal. Behav. 14:1669417. doi: 10.1080/15592324.2019.16 69417

Onguso, J. M. A., Mizutani, F., and Hossain, A. S. (2006). The effect of trunk electric vibration on the growth, yield and fruit quality of peach trees (Prunus persica [L.] Batsch). Sci. Horticult. 108, 359-363. doi: $10.1016 /$ j.scienta.2006.02.013

Onoda, Y., and Anten, N. P. R. (2011). Challenges to understand plant responses to wind. Plant Signal. Behav. 6, 1057-1059. doi: 10.4161/psb.6.7.15635

Paul-Victor, C., and Rowe, N. (2011). Effect of mechanical perturbation on the biomechanics, primary growth and secondary tissue development of inflorescence stems of Arabidopsis thaliana. Ann. Bot. 107, 209-218. doi: $10.1093 / \mathrm{aob} / \mathrm{mcq} 227$

Pickard, B. G. (1971). Action potentials resulting from mechanical stimulation of pea epicotyls. Planta 7, 106-115. doi: 10.1007/BF00386758

Pickard, B. G., and Fujiki, M. (2005). Ca2++ pulsation in BY-2 cells and evidence for control of mechanosensory $\mathrm{Ca}^{2++}$-selective channels by the plasmalemmal reticulum. Funct. Plant Biol. 32, 863-879. doi: 10.1071/F P05045

Pomiès, L., Decourteix, M., Franchel, J., Moulia, B., and Leblanc-Fournier, N. (2017). Poplar stem transcriptome is massively remodelled in response to single or repeated mechanical stimuli. BMC Genomics 18:300. doi: 10.1186/s12864-017-3670-1

Prasad, T. K., and Cline, M. G. (1985). Mechanical perturbation-induced ethylene releases apical dominance in Pharbitis nil by restricting shoot growth. Plant Sci. 41, 217-222. doi: 10.1016/0168-9452(85)90092-5

Robitaille, H. A., and Leopold, A. C. (1974). Ethylene and the regulation of apple stem growth under stress. Physiol. Plantarum 32, 301-304. doi: 10.1111/j.1399-3054.1974.tb03139.x

Saidi, I., Ammar, S., Demont-Caulet, N., Thévenin, J., Lapierre, C., Bouzid, S., et al. (2010). Thigmomorphogenesis in Solanum lycopersicum: morphological and biochemical responses in stem after mechanical stimulation. Plant Signal. Behav. 5, 122-125. doi: 10.4161/psb.5.2.10302

Sibaoka, T. (1966). Action potentials in plant organs. Symposium of the Society of Exp. Biol. 20, 165-184. doi: 10.1146/annurev.pp.20.060169.001121

Stelmach, B. A., Müller, A., Hennig, P., Laudert, D., Andert, L., and Weiler, E. W. (1998). Quantitation of the octadecanoid 12-oxo-phytodienoic acid, a signalling compound in plant mechanotransduction. Phytochemistry 47, 539-546. doi: 10.1016/S0031-9422(97)00547-5

Suge, H. (1978). Growth and gibberellin production in Phaseolus vulgaris as affected by mechanical stress. Plant Cell Physiol. 19, 1557-1560.

Sutherland, M. W. (1991). The generation of oxygen radicals during host plant-responses to infection. Physiol. Mol. Plant Pathol. 39, 535-541. doi: 10.1016/0885-5765(91)90020-I

Takahashi, H., and Suge, H. (1980). Sex expression in cucumber plants as affected by mechanical stress. Plant Cell Physiol. 21, 303-310. doi: 10.1093/oxfordjournals.pcp.a076003

Telewski, F. W. (1990). Growth, wood density and ethylene production in response to mechanical perturbation in Pinus taeda. Can. J. For. Res. 20, 1277-1283. doi: 10.1139/X90-170

Telewski, F. W. (1995). "Wind-induced physiological and developmental responses in trees," in Wind and Trees, eds M. P. Coutts and J. Grace (Cambridge: Cambridge University Press), 237-263.

Telewski, F. W. (2006). A unified hypothesis of mechanoperception in plants. Am. J. Bot. 93, 1466-1476. doi: 10.3732/ajb.93.10.1466

Telewski, F. W. (2012). Is windswept tree growth negative thigmotropism? Plant Sci. 184, 20-28. doi: 10.1016/j.plantsci.2011. 12.001
Telewski, F. W. (2016a). "Flexure wood: mechanical stress induced secondary xylem formation," in Secondary Xylem Biology: Origins, Functions and Applications, eds Y.S. Kim, R. Funada, A.P. Singh (Oxford: Elsevier), 73-91.

Telewski, F. W. (2016b). Thigmomorphogenesis: the response of plants to mechanical perturbation. Italus Hortus 23, 1-16. Available online at: https:// www.soihs.it/ItalusHortus/Review/Review\%2028/01\%20Telewski.pdf

Telewski, F. W., Gardner, B. A., White, G., and Plovanich-Jones, A. (1997). "Wind flow around multi-storey buildings and its influence on tree growth," in Plant Biomechanics 1997: Conference Proceedings 7-12 September 1997, Vol. 1 (Reading: The University of Reading), 185-192.

Telewski, F. W., and Jaffe, M. J. (1981). Thigmomorphogenesis: Changes in the morphology and chemical composition induced by mechanical perturbation in six month old Pinus taeda seedlings. Can. J. For. Res. 11, 380-387. doi: $10.1139 / \mathrm{x} 81-051$

Telewski, F. W., and Jaffe, M. J. (1986). Thigmomorphogenesis: the role of ethylene in the response of Pinus taeda and Abies fraseri to mechanical perturbation. Physiol. Plantarum 66, 227-233. doi: 10.1111/j.1399-3054.1986.tb02413.x

Telewski, F. W., and Moore, J. (2016). Trait selection to improve windfirmness in trees. CAB Rev. 11, 1-10. doi: 10.1079/PAVSNNR201611050

Telewski, F. W., and Pruyn, M. L. (1998). Thigmomorphogenesis: a dose response to flexing in Ulmus americana seedlings. Tree Physiol. 18, 65-68. doi: 10.1093/treephys/18.1.65

Thonat, C., Boyer, N., Penel, C., Courduroux,. J. C., and Gaspar, T. (1993). Cytological indication of the involvement of calcium and calcium-related proteins in the early responses ofBryonia dioica to mechanical stimulus. Protoplasma 176, 133-137. doi: 10.1007/BF01378949

Toriyama, H., and Jaffe, M. J. (1972). Migration of calcium and its role in the regulation of seismonasty in the motor cell of Mimosa pudica L. Plant Physiol. 49, 72-81. doi: 10.1104/pp.49.1.72

Tretner, C., Huth, U., and Hause, B. (2008). Mechanostimulation of Medicago truncatula leads to enhanced levels of jasmonic acid. J. Exp. Bot. 59, 2847-2856. doi: $10.1093 / \mathrm{jxb} / \mathrm{ern} 145$

Trewavas, A., and Knight, M. (1994). Mechanical signalling, calcium and plant form. Plant Mol. Biol. 26, 1329-1341. doi: 10.1007/BF00016478

Tsai, Y. C., Delk, N. A., Chowdhury, N. I., and Braam, J. (2007). Arabidopsis potential calcium sensors regulate nitric oxide levels and the transition to flowering. Plant Signal. Behav. 2, 446-454. doi: 10.4161/psb.2.6.4695

Van Breusegem, F., Vranová, E., Dat, J. F., and Inzé, D. (2001). The role of active oxygen species in plant signal transduction. Plant Sci. 161, 405-414. doi: 10.1016/S0168-9452(01)00452-6

Weiler, E. W. (1993). Octadecanoid-derived signaling molecules involved in touch perception in a higher plant. Bot. Acta 106, 2-4. doi: 10.1111/j.1438-8677.1993.tb00330.x

Xu, W., Purugganan, M. M., Polisensky, D. H., Antosiewicz, D. M., Fry, S. C., and Braam, J. (1995). Arabidopsis TCH4, regulated by hormones and the environment, encodes a xyloglucan endotransglycosylase. Plant Cell 7, 1555-1567. doi: 10.1105/tpc.7.10.1555

Yahraus, T., Chandra, S., Legendre, L., and Low, P. S. (1995). Evidence for a mechanically induced oxidative burst. Plant Physiol. 109, 1259-1266. doi: $10.1104 /$ pp.109.4.1259

Conflict of Interest: The author declares that the research was conducted in the absence of any commercial or financial relationships that could be construed as a potential conflict of interest.

Copyright (c) 2021 Telewski. This is an open-access article distributed under the terms of the Creative Commons Attribution License (CC BY). The use, distribution or reproduction in other forums is permitted, provided the original author(s) and the copyright owner(s) are credited and that the original publication in this journal is cited, in accordance with accepted academic practice. No use, distribution or reproduction is permitted which does not comply with these terms. 